\title{
Temtamy preaxial brachydactyly syndrome
}

INSERM

\section{Source}

INSERM. (1999). Orphanet: an online rare disease and orphan drug data base. Temtamy preaxial brachydactyly syndrome. ORPHA:363417

Temtamy preaxial brachydactyly syndrome is a rare, genetic dysostosis syndrome characterized by bilateral, symmetrical, preaxial brachydactyly associated with hyperphalangy, motor developmental delay and intellectual disability, growth retardation, sensorineural hearing loss, dental abnormalities (incuding misalignment of teeth, talon cusps, microdontia), and facial dysmorphism that includes plagiocephaly, round face, hypertelorism, malar hypoplasia, malformed ears, microstomia and micro/retrognathia. 